\title{
REGULAR MATRIX TRANSFORMATION ON TRIPLE SEQUENCE SPACES-I
}

\author{
SHYAMAL DEBNATH and BIMAL CHANDRA DAS
}

\begin{abstract}
The main aim of this article is to establish necessary and sufficient conditions for a six dimensional matrix mapping to be regular on triple sequence spaces.
\end{abstract}

MSC 2010. 40A99, 40A09.

Key words. Triple sequence, regular matrix transformation, divergent triple series, convergent sequence.

\section{REFERENCES}

[1] A. J. Datta, A. Esi and B.C. Tripathy, Statistically convergent triple sequence spaces defined by Orlicz function, J. Math. Anal., 4 (2013), 16-22.

[2] B.C. Das, Some I-convergent triple sequence spaces defined by a sequence of modulus function, Proyecciones, 36 (2017), 117-130.

[3] S. Debnath and B.C. Das, Some new type of difference triple sequence spaces, Palestine J. Math., 4 (2015), 284-290.

[4] S. Debnath, B.C. Das, D. Bhattacharya and J. Debnath, Regular matrix transformation on triple sequence spaces, Bol. Soc. Parana. Mat., 35 (2017), 85-96.

[5] S. Debnath, B. Sharma and B.C. Das, Some generalized triple sequence spaces of real numbers, J. Nonlinear Anal. Optim., 6 (2015), 71-79.

[6] A. Esi and E. Savas, On lacunary statistically convergent triple sequences in probabilistic normed spaces, Appl. Math. Inf. Sci., 9 (2015), 2529-2534.

[7] H. Kizmaz, On certain sequence spaces, Canad. Math. Bull., 24 (1981), 169-176.

[8] P.N. Natarajan, Classical summability theory, Springer, Singapore, 2017.

[9] G.M. Robison, Divergent double sequences and series, Trans. Amer. Math. Soc., 28 (1926), 50-73.

[10] D. Rath and B.C. Tripathy, Matrix maps on sequence spaces associated with sets of integers, Indian J. Pure Appl. Math., 27 (1996), 197-206.

[11] T. Salat, On statistically convergent sequences of real numbers, Math. Slovaca, 30 (1980), 139-150.

[12] A. Sahiner, M. Gurdal and K. Duden, Triple sequences and their statistical convergence, Selçuk J. Appl. Math., 8 (2007), 49-55.

[13] A. Sahiner and B.C. Tripathy, Some I-related properties of triple sequences, Selçuk J. Appl. Math., 9 (2008), 9-18.

[14] E. Savas and A. Esi, Statistical convergence of triple sequences on probabilistic normed spaces, An. Univ. Craiova Ser. Mat. Inform., 39 (2012), 226-236.

The authors thank the referee for his helpful comments and suggestions.

DOI: $10.24193 /$ mathcluj.2018.2.04 
[15] N. Subramaniam and A. Esi, The generalized triple difference of $\chi^{3}$ sequence spaces, Global Journal of Mathematical Analysis, 3 (2015), 54-60.

[16] B.C. Tripathy and A. Esi, A new type of difference sequence spaces, International Journal of Science \& Technology, 1 (2006), 11-14.

[17] B.C. Tripathy and R. Goswami, On triple difference sequences of real numbers in probabilistic normed spaces, Proyecciones, 33 (2014), 157-174.

[18] B.C. Tripathy and R. Goswami, Vector valued multiple sequences defined by Orlicz functions, Bol. Soc. Parana. Mat., 33 (2015), 67-79.

[19] B.C. Tripathy and B. Sarma, Statistically convergent difference double sequence spaces, Acta Math. Sin. (Engl. Ser.), 24 (2008), 737-742.

Received November 23, 2017

Tripura University (A Central University)

Accepted January 10, 2018

Department of Mathematics

Suryamaninagar-799022, Agartala, India

E-mail: shyamalnitamath@gmail.com

Government Degree College

Department of Mathematics

Kamalpur-799285

Dhalai, Tripura, India

E-mail: bcdas3744@gmail.com 